Jurnal Media Pertanian Vol. 1 No. 2 Tahun 2016 Hal. 45 - 54

Media Komunikasi Hasil Penelitian dan Review Literatur Bidang Ilmu Agronomi ISSN $2503-1279$

\title{
KARAKTERISTIK FISIK dan PRODUKSI KELAPA DALAM (Cocos nucifera L) di BERBAGAI EKOLOGI LAHAN
}

\author{
Rudi Hartawan ${ }^{1 *}$ dan Arif Sarjono ${ }^{2}$ \\ ${ }^{1}$ Program studi Agroteknologi, Fakultas Pertanian Universitas Batanghari \\ Jl. Slamet Riyadi-Broni, Jambi. 36122. Telp. +62074160103 \\ ${ }^{2}$ Alumni Program studi Agroteknologi, Fakultas Pertanian Universitas Batanghari \\ *email korespondensi : rudi2810@yahoo.com
}

\begin{abstract}
The growing environment plays an important role in the plant's phenotype. The suitability of the environment will bring up the genetic potential mainly on coconut production. The expected output of this research is to know the adaptation level of coconut crops different land ecology. The research was carried out in January to August 2016 at: 1) tidal lands in Lagan Ulu village of Geragai Sub-district of Tanjung Jabung Timur with altitude 0-10 m above sea level, 2) in the lowland Ramin village Kumpeh Ulu Subdistrict Muaro Jambi regency with a height of 10-100 m above sea level, 3) Moderate land in Wanareja village of Rimbo Ulu Subdistrict Tebo regency with an altitude of 100-500 $\mathrm{m}$ above sea level and 4) Highland in Seberang village Sungai Penuh subdistrick Sungai Penuh City, with an altitude $500 \mathrm{~m}$ above sea level. Laboratory analysis conducted in July 2016 in laboratorium dasar University Batanghari. Research conducted by survey methods in community gardens and arranged in environment randomized block design namely tidal areas, lowland, moderate land, and highland. Each altitude of land was three farmers. Porposifly as a block of design. The parameters are the palnt physical, reproduction age, agronomy, action estimation of production potential, soil acidity and daily temperatures. Data of research are analyzed by description method such as tabulated data form and anova test $(\alpha=5 \%)$ was used of inferential analysis. The result of this research showed that there was a significantly effect of land altitude on production potential and phisical characteristic of coconut trees. The coconut trees showed optimally growth and production in moderate land (100-500m above sea level).
\end{abstract}

Keywords: coconut, cultivation, crop production.

\begin{abstract}
Abstrak
Lingkungan tumbuh berperan penting dalam produksi tanaman Kelapa Dalam. Tujuan dari penelitian ini adalah mengetahui tingkat adaptasi tanaman Kelapa Dalam pada berbagai ekologi lahan. Penelitian dilaksanakan pada bulan Januari sampai Agustus 2016 di: 1) lahan pasang surut di Desa Lagan Ulu, Kecamatan Geragai, Kabupaten Tanjung Jabung Timur dengan ketinggian 0-10 m dpl, 2) dataran rendah di Desa Ramin, Kecamatan Kumpeh Ulu, Kabupaten Muaro Jambi dengan ketinggian 10-100 m dpl, 3) dataran sedang di Desa Wanareja, Kecamatan Rimbo Ulu, Kabupaten Tebo dengan ketinggian 100-500 m dpl dan 4) dataran tinggi di Desa Seberang, Kecamatan Sungai Penuh, Kota Sungai Penuh, dengan ketinggian $>500 \mathrm{~m}$ dpl. Analisis laboratorium dilakukan pada bulan Juli 2016 di Laboratorium Dasar Universitas Batanghari. Penelitian dilakukan dengan metode survey di kebun-kebun masyarakat dan disusun dalam rancangan lingkungan acak kelompok dengan rancangan perlakuan ekologi lahan yaitu daerah pasang surut, dataran rendah, dateran sedang dan dataran tinggi. Tiap-tiap ekologi lahan diambil tiga petani sampel secara sengaja yang dijadikan blok dalam rancangan. Peubah yang diamati adalah fisik tanaman, umur berproduksi, tindakan agronomi, estimasi potensi produksi, kemasaman tanah dan suhu harian. Data hasil penelitian dianalisis dengan metode deskripsi dalam bentuk tabulasi dan inferensi dilakukan dengan uji anova taraf $\alpha 5 \%$. Hasil penelitian menunjukkan Ekologi lahan berpengaruh nyata terhadap potensi produksi dan karakteristik fisik
\end{abstract}


Jurnal Media Pertanian Vol. 1 No. 2 Tahun 2016 Hal. 45 - 54

Media Komunikasi Hasil Penelitian dan Review Literatur Bidang Ilmu Agronomi

ISSN $2503-1279$

tanaman Kelapa Dalam. Tanaman Kelapa Dalam dapat tumbuh, berkembang dan berproduksi dengan baik di daerah dataran sedang dengan ketinggian 100-500 m dpl.

Kata kunci: Kelapa Dalam, budidaya, produksi tanaman

\section{PENDAHULUAN}

Kelapa (Cocos nucifera L.) merupakan komoditas strategis yang memiliki peran sosial, budaya, dan ekonomi dalam kehidupan masyarakat Indonesia. Di Provinsi Jambi, perkebunan Kelapa Dalam itu tersebar di sepuluh kabupaten dan kota. Luas tanam Kelapa Dalam pada tahun 2014 mencapai 117.466 hektar dengan total produksi 107.566 ton. Produktivitas tanaman kurang dari 1 ton ha ${ }^{-1}$ dan bervariasi berdasarkan ekologi lahan (Biro Pusat Statistik, 2015).

Provinsi Jambi memiliki empat macam ekologi lahan; dataran rendah 0-100 meter dari permukaan laut (m dpl) meliputi Kota Jambi, Kabupaten Tanjung Jabung Barat, Kabupaten Tanjung Jabung Timur, Batanghari, Bungo, Kabupaten Tebo, Kabupaten Sarolangun dan Kabupaten Merangin. Daerah dengan ketinggian sedang 100-500 m dpl meliputi Bungo, Kabupaten Tebo, Kabupaten Sarolangun dan Kabupaten Merangin serta Kabupaten Batanghari. Daerah dataran tinggi $>500 \mathrm{~m}$ dpl meliputi Kabupaten Kerinci, Kota Sungai Penuh, Kabupaten Merangin. Kabupaten Bungo, Kabupaten Tebo dan Kabupaten Sarolangun (Bappeda Provinsi Jambi, 2010).

Beberapa hasil penelitian menunjukkan adanya perbedaan produksi karena perbedaan kondisi lahan. Pambudi dan Hermawan (2010) menunjukkan perbedaan bobot tandan buah segar kelapa sawit karena kemiringan lahan. Semakin miring lahan maka bobot tandan buah segar semakin rendah. Hasil penelitian Prasetio (2013) menunjukkan adanya perbedaan karakteristik fisik tanaman dan mutu lateks dari tanaman karet yang dibudidayakan pada agroekologi lahan yang berbeda. Sama halnya dengan Kelapa Dalam, perbedaan produktivitas itu diduga karena perbedaan ekologi lahan.

Lingkungan tumbuh berperan penting dalam fenotip tanaman. Kecocokan lingkungan akan akan memunculkan potensi genetik terutama produksi. Ekologi akan mempengaruhi iklim dan secara langsung akan mempengaruhi lingkungan tumbuh tanaman. Tanaman Kelapa Dalam dapat tumbuh baik pada ekologi antara 0 sampai 600 meter dari permukaan laut (mdpl) bahkan sampai ketinggian 1200 mdpl. Variasi yang lebar ini menimbulkan dua pertanyaan; pertama: apakah tanaman kelapa beradaptasi luas dengan altititude tanpa mempengaruhi produksi dan kedua apakah tanaman Kelapa Dalam mampu tumbuh dengan baik pada variasi ekologi tinggi tapi akan mempengaruhi produksi? Pertanyaan ini telah terjawab melalui penggalian data empiris dari penelitian yang telah dilaksanakan.

\section{METODE PENELITIAN}

Penelitian ini dilaksanakan pada bulan April sampai Agustus 2016 di berbagai ekologi lahan; 1) lahan dataran rendah pasang surut (pasang surut) di Desa Lagan Ulu Kecamatan Geragai, Kabupaten Tanjung Jabung Timur, dengan ketinggian 0-10 m dpl. 2) dataran rendah di Desa Ramin, Kecamatan Kumpeh Ulu, Kabupaten Muaro Jambi, dengan ketinggian 10-100 m dpl. 3) Dataran sedang di Desa Wanareja, Kecamatan Rimbo Ulu, Kabupaten Tebo, dengan ketinggian 100-500 m dpl. dan 4) Dataran tinggi di Desa Seberang, Kecamatan Sungai Penuh, Kota Sungai Penuh, dengan ketinggian 
Jurnal Media Pertanian Vol. 1 No. 2 Tahun 2016 Hal. 45 - 54

Media Komunikasi Hasil Penelitian dan Review Literatur Bidang Ilmu Agronomi ISSN $2503-1279$

$>500 \mathrm{~m}$ dpl. Analisis laboratorium dilakukan pada bulan Juni 2016 di Laboratorium Dasar Universitas Batanghari.

Bahan yang digunakan dalam penelitian ini adalah tanaman Kelapa Dalam yang terdapat pada berbagai ekologi lahan. Alat yang digunakan dalam penelitian ini meliputi global positioning service (GPS) receiver (Garmin), meteran, timbangan (Digital Weight), pH meter (Soil Tester), pengukur ketebalan daun (Dial Thicness), bagan warna daun (BWD), lembar kuisioner dan alat perekam.

Penelitian dilakukan dengan metode survey di kebun-kebun masyarakat dan disusun dalam rancangan lingkungan acak kelompok dengan rancangan perlakuan adalah ekologi lahan penelitian yaitu daerah dataran rendah pasang surut, dataran rendah, dateran sedang dan dataran inggi. Setiap ekologi lahan diambil tiga petani sampel secara sengaja yang dijadikan blok seperti yang ditunjuk pada bagan berikut :

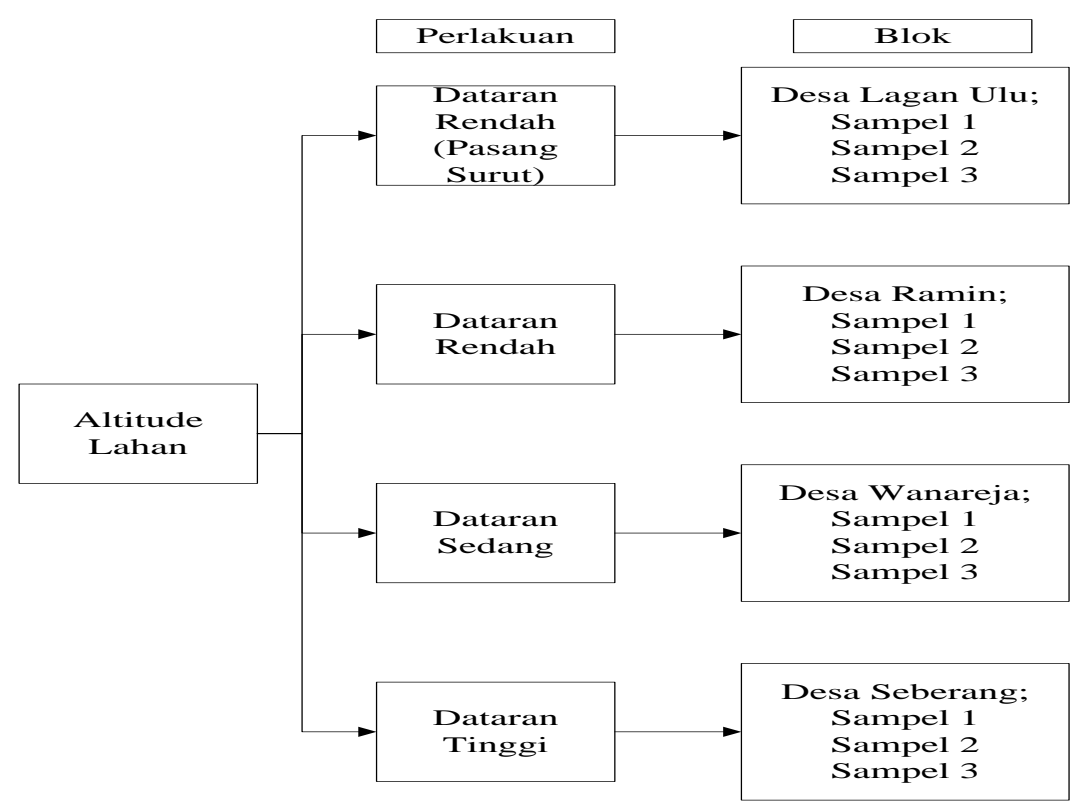

Gambar 1. Lokasi survey dan petani sampel

Penelitian diawali dengan menentukan lokasi-lokasi penelitian berdasarkan ekologi lahan. Selanjutnya setiap ekologi lahan dipilih desa-desa secara sengaja dan ditentukan tiga orang petani sampel yang memiliki kebun kelapa. Jumlah sampel pohon kelapa dipilih berdasarkan metode pengambilan sampel. Syarat tanaman sampel adalah tanaman milik rakyat dan umur produksi tanaman 15-25 tahun.

Metode pengambilan sampel mengunakan metode SRS (simple random sampling) dimana jumlah populasi tanaman lebih dari 100 maka tanaman sampel sebanyak 15\% sedangkan populasi tanaman kurang dari 100 maka tanaman sampel sebanyak 50\% (Tasri, 2007). Tanaman sampel dipilih secara sengaja, tanaman yang dijadikan sampel dilihat titik koordinat dan ketinggian tempat dengan mengunakan GPS.

Peubah yang diamati adalah: 1) Fisik Tanaman yang meliputi a) Lingkar Batang, dilakukan dengan mengunakan meteran. Dihitung dengan cara mengambil rata-rata lingkar pangkal batang, lingkar tengah dan lingkar ujung batang; b) Panjang pelepah diukur dengan cara mengukur pelepah yang sudah tua sehingga dapat mengukur dari pangkal pelepah hingga ujung pelepah dengan mengunakan meteran; c) Lingkar Buah 
Jurnal Media Pertanian Vol. 1 No. 2 Tahun 2016 Hal. 45 - 54

Media Komunikasi Hasil Penelitian dan Review Literatur Bidang Ilmu Agronomi ISSN $2503-1279$

dengan cara mengukur lingkar buah yang sudah matang dengan mengunakan alat pengukur meteran; d) Jumlah Buah Setiap Tandan dengan cara menghitung rata-rata jumlah buah dalam satu tahun disetiap pohon dengan cara menghitung manual diatas pohon kelapa; e) Jumlah Tandan Buah Setiap Pohon ditentukan dengan cara menghitung jumlah tandan seiringan dengan penghitungan jumlah buah kelapa; f) Berat Buah Dengan Sabut dakukan dengan cara memetik buah yang sudah matang kemudian buah dibersihkan dari tangkai buah dan kelopak buah kemudian buah ditimbang mengunakan timbangan digital yang sudah disetandarkan dengaan berat uji; g) Berat Buah Tidak Dengan Sabut dilakukan dengan cara mengupas sabut buah kelapa dari tempurung buah kelapa hingga bersih selanjutnya buah di timbang dengan mengunakan timbangan; h) Ketebalan Daun dengan cara mengukur tebalnya daun menggunakan alat pengukur ketebalan daun (Dial Thicness); i) Warna Daun diukur dengan cara mencocokkan warna daun dengan warna pada bagan warna daun (BWD) dan $\mathrm{j}$ ) Serangan Hama dan Penyakit maka dilakukan pengamatan secara visual di lapangan terhadap fisik tanaman. 2) Umur Mulai Produksi dilakukan wawancara terhadap petani Kelapa; dan 3) Estimasi Potensi Produksi dilakukan dengan cara menghitung hasil perkalian dari berat kelapa, jumlah buah setiap tandan, jumlah tandan dalam satu tahun dan jumlah tanaman dalam luasan tertentu. $E P=B K \times J B \times J T$. Keterangan : EP : nilai estimasi produksi; BK : berat buah kelapa; JB : rata-rata jumlah buah setiap tandan dan JT : rata-rata jumlah tandan setiap pohon; 4) Kemasaman Tanah dilakukan pengecekan denga menggunakan $\mathrm{pH}$ meter dan 5) Suhu Harian, dilakukan pengukuran suhu pada pagi, siang dan sore mengunakan termometer suhu.

Data-data yang diperoleh dianalisis statistika dengan metode deskriptif dan inferensi. Metode deskripsi dalam bentuk tabulasi dan inferensi dilakukan dengan uji anova dan dilanjutkan dengan uji wilayah berganda Duncan dengan ketelitian $95 \%$.

\section{HASIL DAN PEMBAHASAN}

Penelitian ini dilakukan terhadap tiga petani sampel di satu desa pada masingmasing daerah survey. Titik koordinat lokasi pada masing-masing petani sampel dapat dilihat pada Tabel 1.

Tabel 1. Lokasi-lokasi sampel penelitian

\begin{tabular}{|c|c|c|c|c|}
\hline \multirow{2}{*}{ Ekologi } & \multirow[t]{2}{*}{ Nama Desa } & \multirow[t]{2}{*}{ Sampel } & \multicolumn{2}{|c|}{ Titik koordinat } \\
\hline & & & Lintang Selatan (LS) & Lintang Timur (LT) \\
\hline \multirow{3}{*}{$\begin{array}{l}\text { Datarn } \\
\text { Rendah } \\
\text { (Pasang } \\
\text { Surut) }\end{array}$} & \multirow{3}{*}{$\begin{array}{l}\text { Lagan Ulu } \\
\text { (Kab. } \\
\text { Tanjabtim) }\end{array}$} & Petani 1 & $\mathrm{~S}=0109^{\prime} 13,09^{\prime \prime}$ & $\mathrm{E}=10345^{\prime} 30,54^{\prime \prime}$ \\
\hline & & Petani 2 & $\mathrm{~S}=0109^{\prime} 29,79^{\prime \prime}$ & $\mathrm{E}=10345^{\prime} 55,66^{\prime \prime}$ \\
\hline & & Petani 3 & $\mathrm{~S}=0109^{\prime} 39,79^{\prime \prime}$ & $\mathrm{E}=10345^{\prime} 59,15^{\prime \prime}$ \\
\hline \multirow{3}{*}{$\begin{array}{l}\text { Dataran } \\
\text { Rendah }\end{array}$} & \multirow{3}{*}{$\begin{array}{l}\text { Ramin } \\
\text { (Kab. Ma. } \\
\text { Jambi) }\end{array}$} & Petani 1 & $\mathrm{~S}=0130^{\prime} 07,83^{\prime}$ & $\mathrm{E}=10348^{\prime} 33,61^{\prime \prime}$ \\
\hline & & Petani 2 & $\mathrm{~S}=0130^{\prime} 12,54^{\prime \prime}$ & $\mathrm{E}=10348^{\prime} 22,54^{\prime \prime}$ \\
\hline & & Petani 3 & $\mathrm{~S}=0130^{\prime} 44,12^{\prime}$, & $\mathrm{E}=10348^{\prime} 22,56^{\prime \prime}$ \\
\hline \multirow{3}{*}{$\begin{array}{l}\text { Dataran } \\
\text { Sedang }\end{array}$} & \multirow{3}{*}{$\begin{array}{l}\text { Wanareja } \\
\text { (Kab. Tebo) }\end{array}$} & Petani 1 & $S=0116^{\prime} 00,03^{\prime \prime}$ & $\mathrm{E}=10203^{\prime} 41,09^{\prime \prime}$ \\
\hline & & Petani 2 & $\mathrm{~S}=0116^{\prime} 15,23^{\prime}$ & $\mathrm{E}=10203^{\prime} 49,99^{\prime \prime}$ \\
\hline & & Petani 3 & $\mathrm{~S}=0116^{\prime} 12,33^{\prime}$, & $\mathrm{E}=10203^{\prime} 23,45^{\prime \prime}$ \\
\hline \multirow{3}{*}{$\begin{array}{l}\text { Dataran } \\
\text { Tinggi }\end{array}$} & \multirow{3}{*}{$\begin{array}{l}\text { Sebrang } \\
\text { (Kota Sei. } \\
\text { Penuh) }\end{array}$} & Petani 1 & $\mathrm{~S}=0201^{\prime} 11,59^{\prime \prime}$ & $\mathrm{E}=10123^{\prime} 42,49^{\prime \prime}$ \\
\hline & & Petani 2 & $\mathrm{~S}=0201^{\prime} 22,12^{\prime \prime}$ & $\mathrm{E}=10123^{\prime} 15,56^{\prime \prime}$ \\
\hline & & Petani 3 & $\mathrm{~S}=0201^{\prime} 30,46^{\prime \prime}$ & $\mathrm{E}=10123^{\prime} 35,66^{\prime \prime}$ \\
\hline
\end{tabular}


Jurnal Media Pertanian Vol. 1 No. 2 Tahun 2016 Hal. 45 - 54

Media Komunikasi Hasil Penelitian dan Review Literatur Bidang Ilmu Agronomi ISSN $2503-1279$

Tabel ini menunjukkan titik koordinat tiap-tiap petak sampel tanaman Kelapa Dalam di masing-masing ekologi lahan. Jarak antar lokasi dapat diukur berdasarkan perbedaan titik koordinat pada garis lintang Selatan (S) dan lintang Timur (E). Pengukuran jarak antar lokasi dapat mengunakan titik koordinat lintang timur saja maupun mengunakan titik lintang selatan saja, dimana setiap detik pada titik koordinat berjarak $30 \mathrm{~m}$. Seperti pada blok satu, terdapat 3 petak sampel yaitu P1 S = 01 09' 13,09', P2 S = 01 09' 29,79' ' dan P3 S = 01 09' 39,79' ' dimana P1 ke P2 berjarak 16 detik atau $480 \mathrm{~m}$ dan jarak dari P2 ke P3 berjarak 10 detik atau $300 \mathrm{~m}$.

Tanaman Kelapa Dalam memiliki syarat tumbuh dengan toleransi yang relatif luas tetapi berkembang optimal pada kondisi tanah yang memiliki fraksi tanah yang banyak dan dalam, serta $\mathrm{pH}$ antara 5,5 sampai dengan 8 (Abdurachman dan Mulyani, 2003). Jenis tanah yang terbagi di beberapa daerah Provinsi Jambi menyebabkan tingkat kemasaman yang berbeda. Hal ini terbukti berdasarkan hasil pengamatan tingkat kemasaman tanah terdapat perbedaan di daerah pasang surut, dataran rendah, dataran sedang dan dataran tinggi, dimana di dataran rendah memiiki $\mathrm{pH}$ yang tinggi dan kemasaman tanah yang rendah atau mendekati netral. Kemasaman tanah yang tinggi dapat menghambat pertumbuhan tanaman karena terjadinya fiksasi unsur $\mathrm{P}$ dan peningkatan unsur $\mathrm{Al}$ dan $\mathrm{Mn}$. Data peubah fisik tanaman disajikan pada Tabel 2 berikut ini.

Tabel 2. Peubah $\mathrm{pH}$ tanah, lingkar batang dan panjang pelepah tanaman Kelapa Dalam pada berbagai ekologi lahan

\begin{tabular}{|c|c|c|c|c|}
\hline \multirow{2}{*}{ No. } & \multirow{2}{*}{ Ekologi } & \multicolumn{3}{|c|}{ Peubah } \\
\hline & & $\mathrm{pH}$ Tanah & Lingkar Batang $(\mathrm{cm})$ & Panjang Pelepah (m) \\
\hline 1. & Pasang Surut & 3,56 a & 81,33 a & 5,85 a \\
\hline 2. & Dataran Rendah & $4,20 \quad b$ & 87,26 a & 5,83 a \\
\hline 3. & Dataran Sedang & $5,20 \quad c$ & $99,63 \quad b$ & $6,05 \quad b$ \\
\hline 4. & Dataran Tinggi & $6,13 \mathrm{~d}$ & $101,43 \quad b$ & $5,74 \quad \mathrm{a}$ \\
\hline
\end{tabular}

Keterangan : Angka-angka yang diikuti dengan huruf kecil yang sama berbeda tidak nyata menurut uji jarak berganda Duncan dengan ketelitian $95 \%$.

Berdasarkan tingkat kemasaman tanah dan kesuburan tanah di berbagai ekologi lahan, dataran tinggi memiliki topsoil yang dalam dengan jenis tanah aluvial yang subur dan kemasaman tanah yang mendekati netral, berbeda dengan dataran sedang yang didominasi tanah jenis ultisol dan dataran rendah yang didominasi tanah gambut atau histosol yang tingkat kemasaman tanahnya semakin tinggi. Menurut Wiedenhoeft (2006) kemasaman tanah yang tinggi mengakibatkan fiksasi unsur P dan peningkatan unsur $\mathrm{Fe}, \mathrm{Al}$ dan $\mathrm{Mn}$ yang bersifat racun bagi tanaman. Unsur $\mathrm{Al}$ dan Fe yang tinggi di dalam tanah menyebabkan terhambatnya pertumbuhan akar sehingga penyerapan unsur hara oleh akar tanaman menjadi terganggu. Daerah dataran tinggi didominasi oleh tanah-tanah vulkanik yang subur untuk pertumbuhan tanaman sehingga di dataran tinggi tanaman kelapa dapat memenuhi kebutuhan akan unsur hara. Selain kemasaman tanah, ekologi lahan juga mempengaruh suhu harian seperti ditunjukkan pada Gambar 2. 


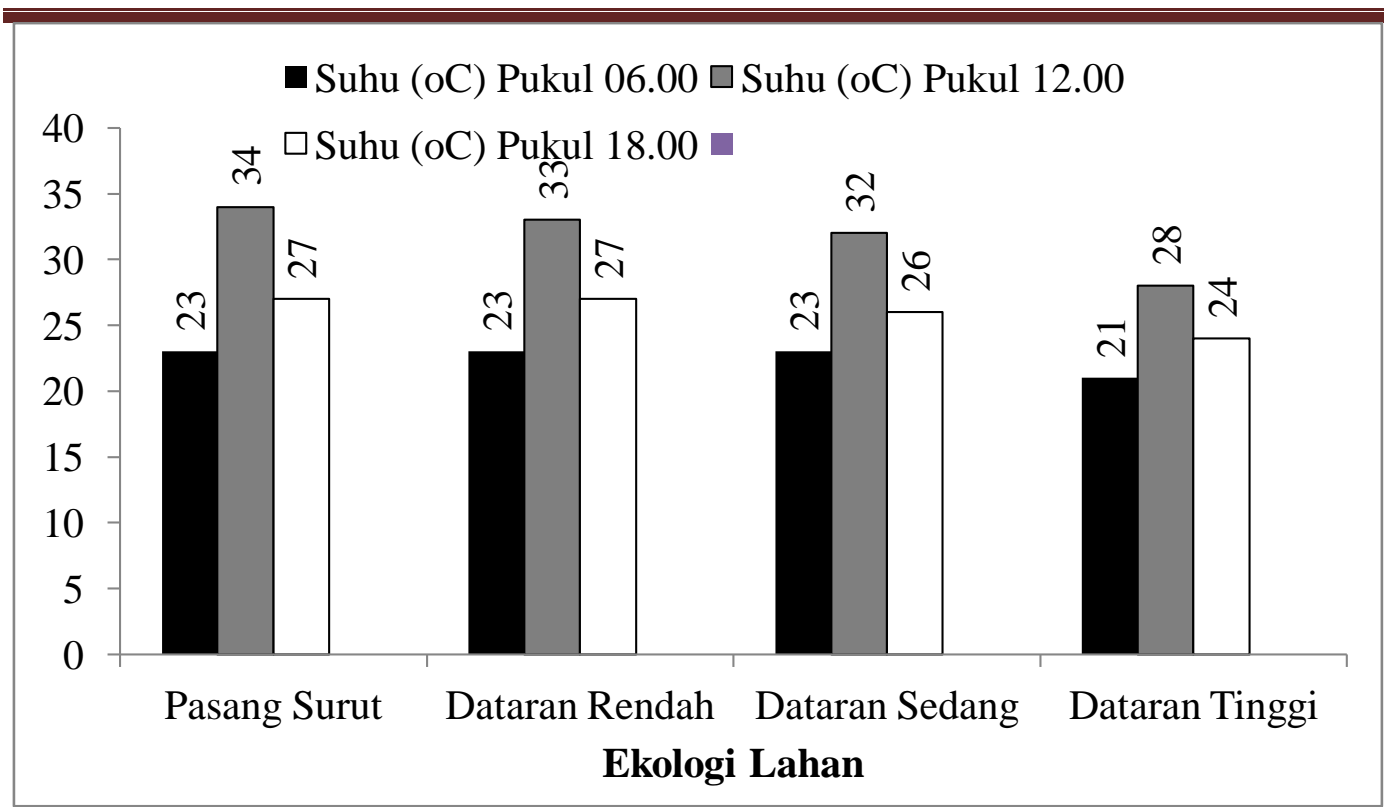

Gambar 2. Rata-rata suhu harian di daerah pasang surut, dataran rendah, dataran sedang dan dataran tinggi

Gambar 2 menunjukan perbedaan suhu harian di daerah pasang surut, dataran rendah, dataran sedang dan dataran tinggi, dimana dataran tinggi memiliki suhu harian lebih rendah dibandingkan suhu harian di dataran rendah dan dataran sedang. Perbedaan tersebut disebabkan Ekologi lahan penelitian yang berbeda-beda diamana ekologi lahan dataran tinggi berada di ketinggian lebih dari $500 \mathrm{~m}$ dpl, dataran sedang $100-500 \mathrm{~m}$ dpl dan dataran rendah kurang dari $100 \mathrm{~m}$ dpl. Perbedaan ekologi lahan menyebabkan terjadinya gejala lapse rate pada suhu harian lokasi penelitian. Gejala lapse rate adalah terjadinya penurunan suhu disetiap kenaikan ketinggian tempat dimana setiap kenaikan ketinggian $100 \mathrm{~m}$ dpl maka suhu akan menurun sebanyak $0,5^{\circ} \mathrm{C}$.

Berdasarkan hasil pengamatan suhu harian di berbagai ekologi lahan Provinsi Jambi, dataran tinggi Provinsi Jambi memiliki suhu terendah $21^{\circ} \mathrm{C}$ berbeda dengan daerah pasang surut $23^{\circ} \mathrm{C}$, dataran rendah $23^{\circ} \mathrm{C}$ dan dataran sedang $23^{\circ} \mathrm{C}$ yang memiliki suhu lebih optimum untuk pertumbuhan kelapa. Perbedaan suhu dapat dilihat terhadap perbedaan pada jumlah tandan setiap pohon dan umur mulai produksi. Pengaruh suhu yang rendah menyebabkan aktivitas metabolisme tanaman kelapa di dataran tinggi menjadi terhambat karena aktivitas kerja enzim katalase yang melambat, metabolisme yang terhambat menyebabkan lamanya tanaman dalam membentuk sel dan jaringan baru sehingga jumlah bakal buah lebih rendah (Lihat Tabel 4).

Suhu juga berpengaruh terhadap laju serangan hama (serangga) pada tanaman kelapa. Serangga tidak aktif di daerah dengan suhu rendah atau di daerah dataran tinggi akan tetapi aktif di daerah dataran rendah yang panas. Serangga oryctes rhinoceros merupakan seranga pengerek yang banyak ditemukan pada lokasi pertanaman tanaman Kelapa Dalam. Serangga ini tidak aktif pada daerah suhu rendah karena merupakan hewan berdarah panas sehingga metabolisme tubuh menurun pada saat berada di daerah bersuhu rendah dan menyebabkan aktivitas tubuh menurun. Tiratabha rufivena merupakan kupu-kupu yang banyak ditemukan pada ekologi pasang surut dan dataran tinggi. Kupu-kupu ini meletakkan larfa pada daun muda tanaman kelapa. Larfa ulat Tiratabha rufivena lebih aktif pada daerah basah seperti pasang surut dan daerah yang 
Jurnal Media Pertanian Vol. 1 No. 2 Tahun 2016 Hal. 45 - 54

Media Komunikasi Hasil Penelitian dan Review Literatur Bidang Ilmu Agronomi ISSN $2503-1279$

bersuhu rendah di dataran tinggi dan kurang aktif pada daerah kering dan panas, karena ulat banyak memakan dedaunan sebagai energi untuk metamorfosis menjadi kupu-kupu. Di daerah yang sejuk dan dingin membuat ulat aktif mencerna daun. Apabila berada di daerah kering dan panas, ulat tidak banyak beraktivitas karena membutuhkan banyak energi sehingga aktifitas tubuh berkurang pada suhu tubuh yang tinggi.

Menurut Getunelnd (2011), bahwa ekologi juga berdampak terhadap intensitas cahaya, dimana pada langit dataran tinggi banyak terdapat awan yang akan mengurangi intensitas cahaya yang diterima oleh tanaman. Pengaruh cahaya bukan hanya bergantung kepada intensitas cahaya saja, namun ada faktor lain yang terdapat pada cahaya, yaitu berkaitan dengan panjang gelombangnya.

Hasil penelitian ini menunjukkan warna daun Kelapa Dalam di dataran tinggi berwarna hijau gelap. Penyinaran yang berkurang karena kabut dan terlindungi awan di dataran tinggi menyebabkan daun tanaman akan menebal dan berwarna hijau gelap, sedangkan di daerah dataran rendah penyinaran yang panjang menjadikan daun lebih lebar, warnanya hijau terang, ketebalan daun lebih tipis yang berfungsi mempercepat proses transpirasi.

Ketebalan daun, warna daun, panjang pelepah, lingkar buah dan berat buah tanaman Kelapa Dalam berbeda-beda dimasing-masing ketinggian. Lamanya penyinaran dan intensitas cahaya matahari yang diterima tanaman kelapa di dataran sedang dan dataran rendah menyebabkan tanaman aktif berfotosintesis. Tanaman kelapa di dataran tinggi mendapatkan lama penyinaran matahari yang lebih sedikit dibanding dataran rendah dan dataran sedang sehingga klorofil di dalam daun tanaman kelapa di dataran tinggi tidak aktif berfotosintesis sehingga warna daun tanaman kelapa di dataran tinggi lebih gelap dibanding daerah lain (Gambar 3).

Selain penyinaran matahari dan intensitas cahaya yang lebih rendah, di dataran tinggi memiliki suhu lebih rendah dibanding daerah lain. Suhu yang rendah dan cahaya matahari yang sedikit menyebabkan terbentuknya jaringan mesofil daun pada daun tanaman kelapa di dataran tinggi sehingga daun tanaman kelapa di dataran tinggi lebih tebal dibanding daun tanaman kelapa di daerah lain.

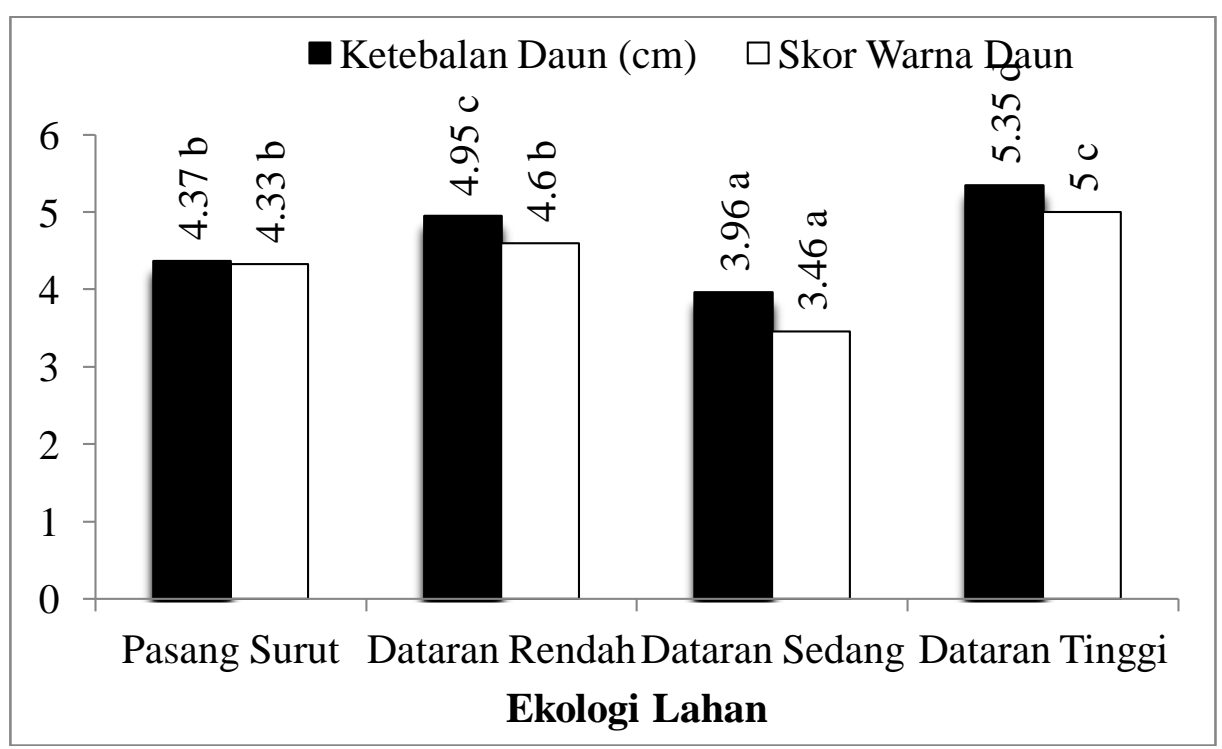

Gambar 3. Ketebalan daun dan warna daun tanaman Kelapa Dalam pada berbagai ekologi lahan 
Jurnal Media Pertanian Vol. 1 No. 2 Tahun 2016 Hal. 45 - 54

Media Komunikasi Hasil Penelitian dan Review Literatur Bidang Ilmu Agronomi ISSN $2503-1279$

Fotosintat yang dihasilkan dari proses fotosintesis tanaman kelapa di dataran sedang lebih banyak dihasilkan dibanding tanaman kelapa di dataran tinggi karena tersedianya cahaya dan $\mathrm{pH}$ tanah yang baik untuk pertumbuhan tanaman sehingga pertumbuhan tanaman di dataran sedang lebih optimum. Pertumbuhan panjang pelepah daun dan jumlah buah dalam setiap tandan dipengaruhi oleh banyaknya fotosintat yang dihasilkan. Tanaman yang dapat menghasilkan fotosintat yang banyak maka pertumbuhan tanaman dan perkembangan sel reproduksinya akan baik dan apabila fotosintat yang dihasilkan tanaman rendah maka pertumbuhan dan reproduksi tanaman akan terhambat.

Rendahnya aktivitas fotosintesis tanaman kelapa di dataran tinggi menyebabkan rendahnya fotosintat dan energi untuk perkembangan buah kelapa. Perkembagan buah yang lambat menyebabkan lingkar buah dan berat buah dengan sabut tanaman kelapa di dataran tinggi lebih kecil dan lebih ringan daripada buah kelapa di daerah datran rendah dan dataran sedang (Tabel 4). Meskipun pekembangan buah tanaman kelapa di dataran tinggi lebih lambat, namun berat biji atau berat buah tidak dengan sabut buah kelapa di dataran tinggi berbeda tidak nyata dengan berat biji atau buah tidak dengan sabut di daerah lain karena cadangan makanan tanaman kelapa didataran tinggi banyak disimpan didalam biji sehingga meskipun kecil tapi memiliki masa yang berat.

Tabel 4. Peubah lingkar buah, jumlah buah setiap tandan, berat buah dengan sabut dan berat buah tanpa sabut tanaman Kelapa Dalam pada berbagai ekologi lahan

\begin{tabular}{|c|c|c|c|c|c|c|c|c|c|}
\hline \multirow[b]{2}{*}{ No. } & \multirow[b]{2}{*}{ Ekologi } & \multicolumn{8}{|c|}{ Peubah } \\
\hline & & \multicolumn{2}{|c|}{$\begin{array}{c}\text { Lingkar } \\
\text { Buah }(\mathrm{cm})\end{array}$} & \multicolumn{2}{|c|}{$\begin{array}{l}\text { Jumlah Buah } \\
\text { setiap } \\
\text { Tandan (buah) }\end{array}$} & \multicolumn{2}{|c|}{$\begin{array}{c}\text { Berat Buah } \\
\text { dengan Sabut } \\
(\mathrm{kg})\end{array}$} & \multicolumn{2}{|c|}{$\begin{array}{c}\text { Berat Buah } \\
\text { tanpa Sabut } \\
(\mathrm{kg})\end{array}$} \\
\hline 1. & Pasang Surut & 61,63 & $\mathrm{c}$ & 4,83 & $\mathrm{a}$ & 1,73 & $\mathrm{~b}$ & 1,01 & $\mathrm{~b}$ \\
\hline 2. & Dataran Rendah & 59,00 & $\mathrm{~b}$ & 6,40 & $\mathrm{~b}$ & 1,80 & $\mathrm{~b}$ & 1,07 & $\mathrm{~b}$ \\
\hline 3. & Dataran Sedang & 63,03 & $\mathrm{c}$ & 8,53 & $\mathrm{c}$ & 1,73 & $\mathrm{~b}$ & 0,97 & $\mathrm{~b}$ \\
\hline 4. & Dataran Tinggi & 55,53 & $\mathrm{a}$ & 4,36 & $\mathrm{a}$ & 1,45 & a & 1,45 & $\mathrm{a}$ \\
\hline
\end{tabular}

Keterangan : Angka-angka yang diikuti dengan huruf kecil yang sama berbeda tidak nyata menurut uji jarak berganda Duncan dengan ketelitian 95\%.

Berdasarkan hasil penelitian dilapangan menunjukkan bahwa petani tanaman Kelapa Dalam umumnya hanya melakukan pengendalian gulma. Sebagian petani di daerah pasang surut dan dataran rendah melakukan pembuatan saluran air di kebunnya. Kurangnya pengetahuan petani tentang teknik budidaya Kelapa Dalam yang baik menyebabkan pertumbuhan tanaman kelapa di Provinsi Jambi tidak seragam dan berproduksi rendah.

Perkembangan tanaman yang baik menjadiakan tanaman kelapa dapat berproduksi dengan baik. meskipun berat buah tidak dengan sabut tanaman kelapa di daerah dataran tinggi, dataran sedang, dataran rendah dan daerah pasang surut tidak berbeda nyata, perbedaan jumlah buah dan jumlah tandan buah tanamn kelapa menyebabkan estimasi produksi dimasing-masing daerah berbeda-beda. Estimasi produksi tanaman kelapa di dataran sedang lebih tinggi dari daerah lain karena rata-rata jumlah buah dan jumlah tandan buah tanaman kelapa didataran sedang lebih banyak dari daerah lain. 
Jurnal Media Pertanian Vol. 1 No. 2 Tahun 2016 Hal. 45 - 54

Media Komunikasi Hasil Penelitian dan Review Literatur Bidang Ilmu Agronomi ISSN $2503-1279$

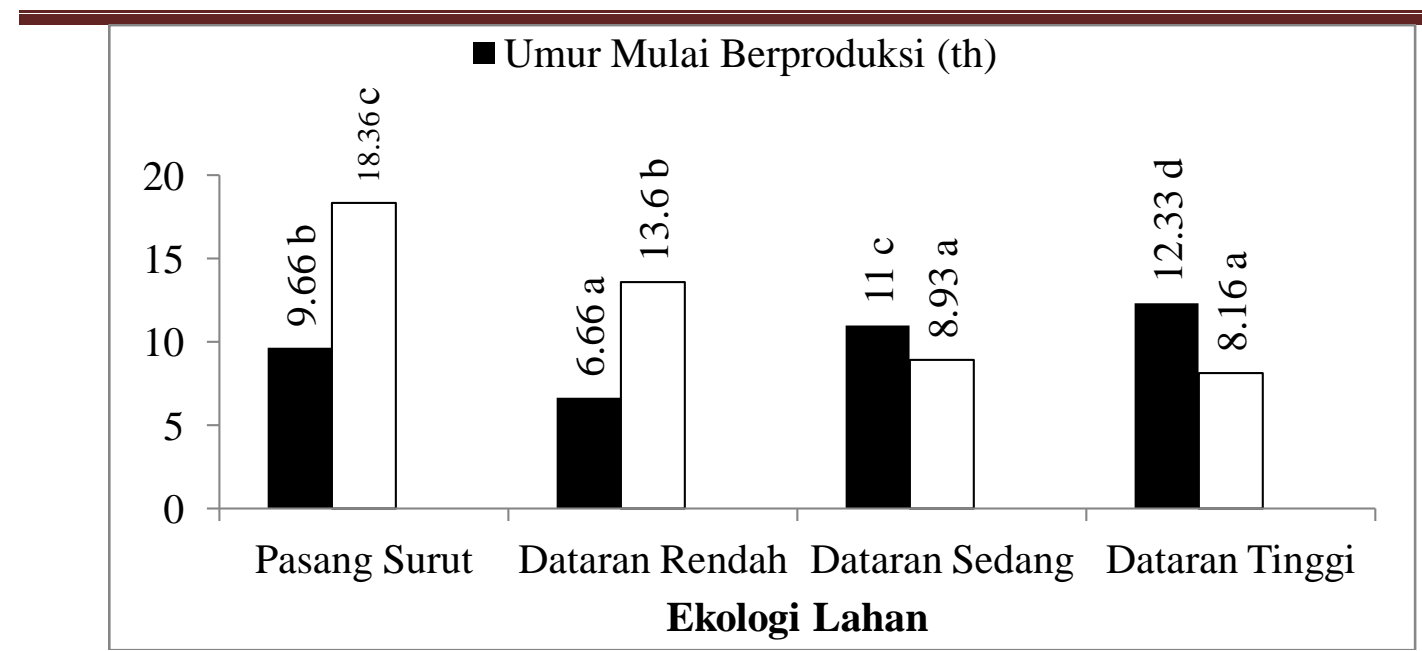

Gambar 3. Umur mulai berproduksi dan potensi produksi tanaman Kelapa Dalam pada berbagai ekologi lahan

Data rill produksi Provinsi Jambi berbeda dengan data estimasi produksi dalam penelitian ini. Perbedaan hasil produksi ini dikarenakan pengambilan data secara estimasi hanya mengunakan data pada saat penelitian saja dan tidak mempertimbangkan pengaruh suhu, cuaca dan musim terhadap produksi dan pertumbuhan tanaman di setiap tahun. Berbeda dengan data dari data Biro Pusat Statistika yang mengunakan data rill berdasarkan produksi tanaman selama satu tahun, sehingga data rill dari Dinas Perkebunan berbeda dengan data estimasi pada penelitian ini.

\section{KESIMPULAN}

Dari tujuan penulisan dan pembahasan yang telah dilakukan, dapat ditarik beberapa kesimpulan bahwa ekologi lahan berpengaruh nyata terhadap potensi produksi dan karakteristik fisik tanaman Kelapa Dalam. Tanaman Kelapa Dalam dapat tumbuh, berkembang dan berproduksi dengan baik di daerah dataran sedang dengan ketinggian 100-500 m dpl.

\section{DAFTAR PUSTAKA}

Abdurachman dan Mulyani. 2003. Kesesuaian lahan tanaman kelapa. (online), (http://www.anakagronomy.com/2013/04/analisis-kesesuaian-lahan-untukanaman.html. Diakses pada tanggal 20 November 2014).

Bappeda Provinsi Jambi. 2010. Gambaran Umum Kondisi Daerah. Jambi.

Biro Pusat Statistik. 2013. Geografis Daerah di Provinsi Jambi. Jambi

Biro Pusat Statistik. 2015. Jambi Dalam Angka 2014. BPS Provinsi Jambi. Jambi

Dinas Perkebunan. 2013. Luas dan Produksi Tanaman Perkebunan Menurut Jenis Tanaman. Jambi.

Gtuneland. 2011. Pengaruh suhu terhadap pertumbuhan. (online). (http://Gtuneland.Wondpress.com. Diakses pada tanggal 10 desember 2015).

Pambudi, D.T. dan B. Hermawan. 2010. Hubungan antara beberapa karakteristik fisik lahan dan produksi Kelapa Sawit. Akta Agosia. Vol. 13 No. 1 Hal. 35-39. Faperta Univ. Bengkulu. 
Jurnal Media Pertanian Vol. 1 No. 2 Tahun 2016 Hal. 45 - 54

Media Komunikasi Hasil Penelitian dan Review Literatur Bidang Ilmu Agronomi ISSN $2503-1279$

Prasetyo, E. 2013. karakteristik fisik tanaman dan mutu lateks dari tanaman karet yang dibudidayakan pada agroekologi lahan yang berbada. Sekripsi. Faperta Unbari.tdk dipublikasikan.

Tasri, E. S. 2007. Metodologi Penelitian Ekonomi Dan Bisnis. Universitas Bung Hatta. Padang.

Wiedenhoeft, A. C. 2006. Plant Nutrition. Chelsea House. USA. 144 p 